\title{
Syria: \\ Terrorism as a catalyst for proxy war - the case of the civil war
}

\author{
Patrycja GŁOGOWSKA
}

\begin{abstract}
The general meaning of "proxy war" is the pursuit of one's interests exploiting other actors. Measures to this end can be implemented in two ways: through hard and soft power. As far as countering the activities of terrorist organizations is concerned, it can be seen that self-interest is placed above efforts against terrorism. The civil war in Syria and the activities of terrorist organizations have become grounds for greater involvement of global powers in the struggle for gaining influence in the country. This paper aims to show the actions of global and regional powers and other state actors taken in an attempt to assert power and influence under the guise of the fight against terrorism. The paper is divided into two parts: theoretical and practical. The theoretical part discusses aspects related to Josepha Nye's concept of "smart power" and the notions of "proxy war" and "proxy activities". The practical part discusses the activities of international actors pursuing their interests through official involvement in the fight against Daesh in the Syrian territory.
\end{abstract}

Keywords: proxy war, Middle East, soft power, hard power, Daesh, Syria.

"War is nothing but a continuation of politics (...). War is not only a political act but a real instrument of politics, a continuation of political intercourse, carried on with other means."

Patrycja GŁOGOWSKA
Faculty of Social Sciences
University of Wrocław, Poland
E-mail: pat.glogowska@gmail.com

Conflict Studies Quarterly

\section{Introduction}

The early 2000s saw massive popular protests against governments in the Middle East and North Africa. The consequences of these protests have varied from country
Issue 36 , July 2021, pp. 22-38

DOI: $10.24193 /$ csq.36.2

Published First Online: 05 July /2021 
to country. In some countries, revolting masses were sufficiently determined to remove their leaders (Egypt, Tunisia), in others, protests led to a prolonged civil war (Syria, Libya, Yemen) whereas in certain states, protests were infrequent and the rulers managed to crush the "rebellions" outright (Bania, Woźniak, \& Zdulski, 2011).

Syria, a country in which the Arab Spring started a civil war in 2011, over time has become a zone of a substitute war waged by external actors. As Bashar al-Assad lost control over parts of the country, the conditions presented for the growth of a terrorist organization known as the Islamic State (or "Daesh", after its transliterated Arabic acronym). Direct actions of this group pose a threat not only at the national level but also at the regional and global level.

Syria is notably a country that not only benefits from an excellent geostrategic position but also, unlike most countries in the region, has access to considerable natural resources. Because of these assets, Syria is attracting a lot of interest from other states. The activities of a terrorist organization such as the Islamic State have enabled the governments of other countries to become involved in the conflict in Syria. Countries that had hitherto had no ally in Assad hoped for an opportunity to change the establishment to one more sympathetic to their policies, while the governments of countries allied to Assad undertook to defend the Syrian president and keep him in office.

The paper presents aspects related to the theoretical framework concerning proxy war, proxy activities and Nye's concept of smart power. The second part of the paper discusses practical aspects of proxy war on three levels, namely the national- regionaland global-level competition in Syria.

\section{Proxy war}

Since the beginning of the formation of states, each has sought superiority over others to ensure their dominance in imposing their will while pursuing their interests. Parzymies defines the notion of power status (Polish: mocarstwowośc) as "the drive to impose one state's supremacy on other states in general or in specific areas, with the subtext of seeking to achieve political, economic and strategic advantages" (Łoś-Nowak, 2002). There are increasingly fewer conventional wars in the 21st century. Nevertheless, the competition between states and their quest for power status has not diminished. Nowadays wars are controlled from the proverbial back seat, and the belligerents are purposively weakened.

The concept of proxy war was first formulated by Czech scientist Karl Deustch. However, already in ancient times, a Chinese general, Tan Daoqi, spoke about the use of deception "to carry out the murder with hired swords" (Galice, 2017, p. 2). This suggests that the need to deal with one's interests through proxy groups has been apparent already in the distant past. In 1964, Deutsch defined proxy war as a conflict between two powers 
using a third country's population, territory and resources (Porter, 2015). However, this definition is incomplete; it does not describe the conflicts of the twenty-first century, which may be called proxy wars because of their very nature. Syria is a good example of this. Syria is a place where many external actors carry out their activities overtly or covertly. On the other hand, the definition of a proxy given by Geraint Hughes is oriented on the internal actor. According to Hughes, proxy war occurs whenever a group directly involved in a country at war receives foreign assistance. Such assistance determines a proxy war if the relationship between the interested parties meets three criteria: there must be direct support, a common enemy and a long-standing relationship between the parties. One of the above-mentioned criteria can be perceived in different ways. After all, what does a long-standing relationship really mean? The case of the Federal Republic of Germany and its assistance to the Kurds contradicts this argument. The relationship in question is not long-standing, because the Kurds had not been trained by the German military until Western states became more involved in the Syrian conflict. For Germany, this is a proxy measure. Germany's strategic goals include improving the country's position within NATO. However, Germany does not want to achieve this goal by sending soldiers directly to the areas of hostilities; it rather opts for an indirect military commitment-the training of the Kurds. Another academic, Andrew Mumford (2013), describes proxy war as a third-party's direct involvement in a conflict to pursue the third party's interests. This definition is debunked by the practices of state actors in Syria: certain foreign actors are unwilling to engage directly and use their proxies instead

Defining the Syrian conflict is not an easy exercise. Experts are debating whether it can already be called a proxy war. Analyst and president of the Eurasia Group, Cliff Kupchan, says the conflict in Syria is not a proxy war. He argues that a proxy war involves two states supporting opposing sides in the conflict. Another academic, John McLaughlin of Johns Hopkins University, claims that the war in Syria is not yet a proxy war. According to McLaughlin, the situation is very fluid and it is difficult to determine if the conflict will develop into a proxy war. Stephen D. Biddle, on the other hand, believes that the Syrian conflict is a proxy war since it can be defined as a war in which foreign actors use local forces to pursue their agendas (cited in Peralta, 2015).

Due to its multisided nature and a large stakeholder group involved, the conflict in Syria is complex and constitutes an element of hidden wars between foreign powers. Given the above characteristics, the Syrian conflict can be called a multisided proxy war (Çağlayan, 2016), which means that the hostilities occurring in Syria are multilateral in nature.

An important factor that defines, and is undoubtedly correlated with, a proxy war is the existence of multiple levels of competition between different actors. A proxy war is determined by its levels. A conflict that takes place locally, within a state, involves 
regional and global actors. What matters is the level of competition. The actors compete horizontally, but their actions are directed to a lower level. Examples include the competition between the Islamic Republic of Iran and the Kingdom of Saudi Arabia taking place as both countries are engaged in the war in Syria on opposite sides, or that between the United States and the Russian Federation, whose actions are also geared towards the opposite sides of the Syrian conflict. The significance of impact levels is also indirect. In a conflict like that in Syria, there are three impact levels: global, regional and national. However, cooperation and proxy activities also occur at intermediate levels. For example, Russia (a global-level actor) supports the regime of Bashar al-Assad (at the national level) with the help of Iran (Russia's partner at the regional level). This is important because global actors can perform certain activities in a country where war is raging by providing support to other countries in the region, which are called upon to provide their forces and resources to attain a given objective.

Multisided competition

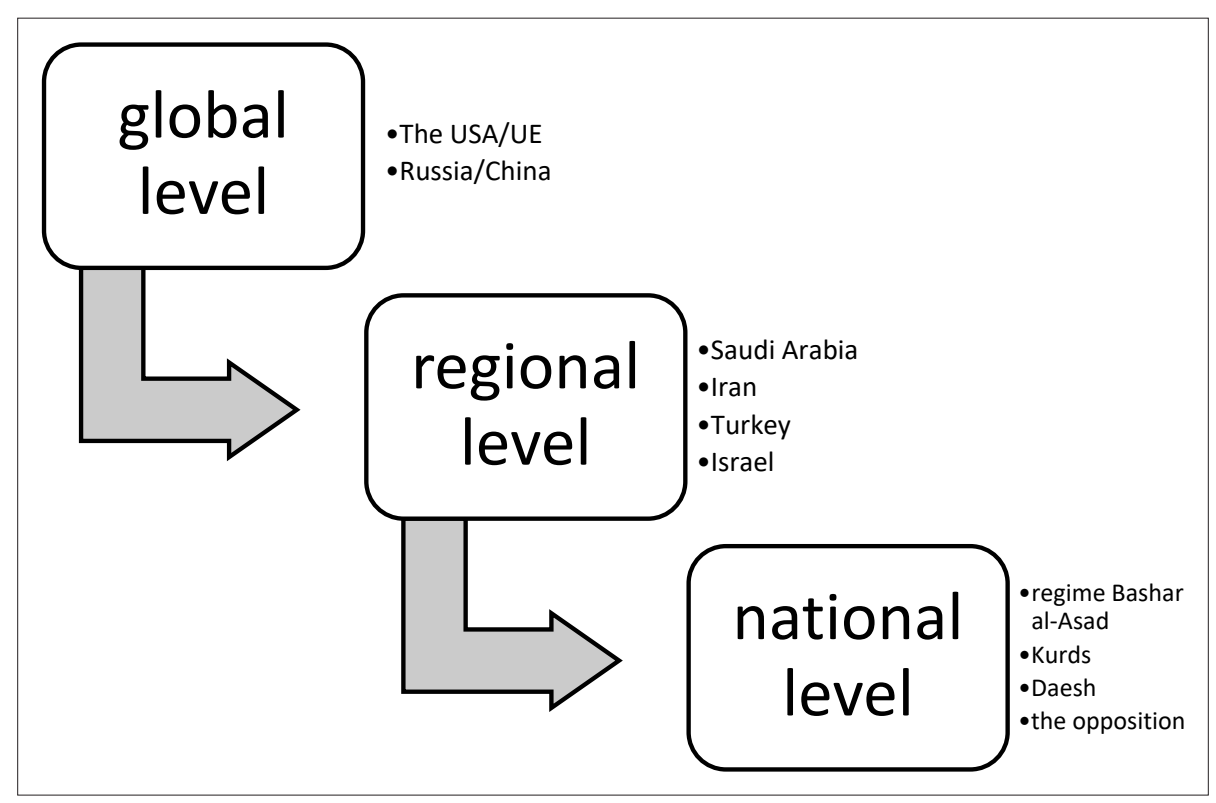

Source: own elaboration

Another issue related to the definition of proxy war is the duration of the relationship with the proxy. The U.S. military tends to view a proxy as an agent with unlimited willingness to cooperate. However, such cooperation may be of limited duration because, as the agent becomes more capable, they may want to disengage or other actors may identify, and exploit, the agent's vulnerabilities (Fox, 2019). 


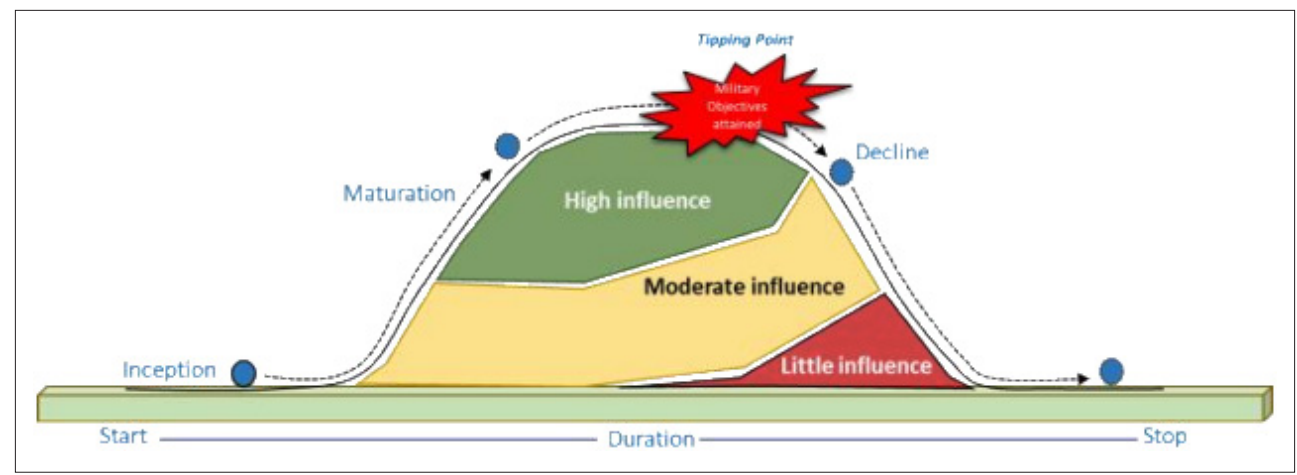

Source: Fox (2019)

\section{The concept of Joseph Nye}

A prominent American political scientist took it upon himself to define a way of conducting politics that would pursue the interests of the state in the most beneficial way. As an example, he used America, the only superpower which is also the researcher's homeland. The US dominance in the international arena allowed him to analyze the policy it was pursuing and draw conclusions for the future. Nye formulated the concept of smart power, which is the combination of hard and soft power (Miłoszewska, 2010). Conducting a policy according to the principles of smart power, i.e. pursuing a prudent and wise policy, is supposed to bring nothing but benefits to the state. Hard power is the pursuit of policy by force or coercion. Given how interests were advanced in the past, it is hard to think of another method. This group also includes impact factors such as raw materials, military factors, economics and technology. The above areas of influencing other countries are classified as hard power, as their use is more a matter of blackmail and force than non-violent actions. Instruments that are applied to areas of hard power include violence, bribery, sanctions or blackmail. The second type of smart power is soft power. It is a concept that lies between the attractiveness of culture, the conduct of policy by individual countries and persuading other countries to implement the activities designated by them (Miłoszewska, 2010). Areas that allow for interests to be pursued through soft power is social cohesion, which is a determinant of multilateralism rather than unilateralism. Another factor is cultural attractiveness and compliance with the decisions of the United Nations and international law. Instruments through which individual areas of soft power can be implemented include cultural, religious institutions, and diplomacy. 
The concept of smart power

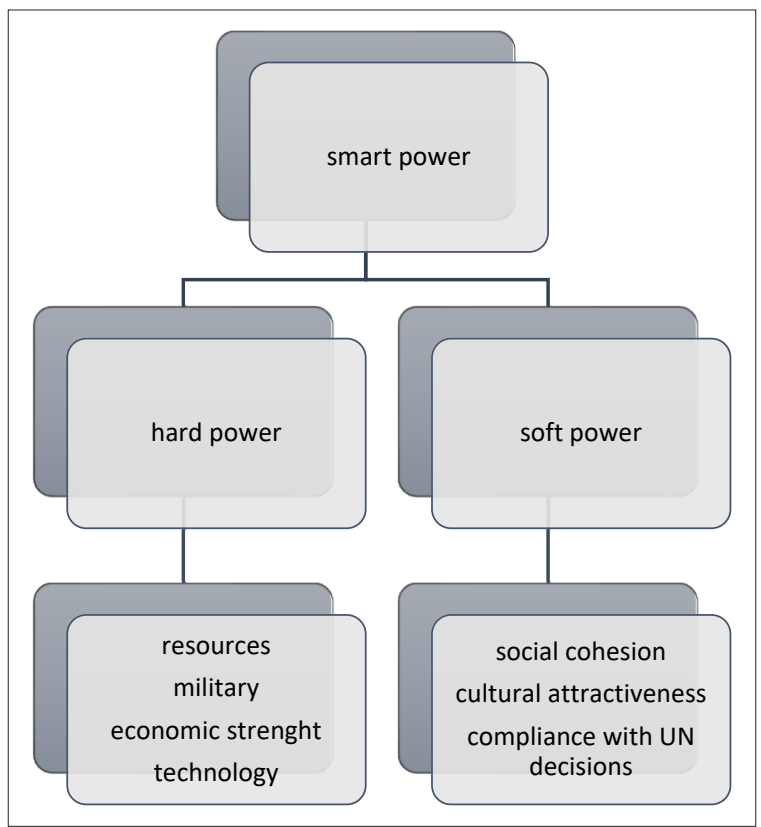

Source: own elaboration based on

D. Miłoszewska, Trójpłaszczyznowa szachownica, Częstochowa 2010.

\section{Proxy activities in smart power}

The concept of proxy war defines the activities of states in internal conflicts of other countries. In other words, proxy war is all the activities of external actors that are aimed at furthering their interests. However, this theory applies only to wars. It is well known that states aspire to become powers. In the age of globalization, relations, cooperation and the supremacy of some countries over others are the order of the day in international relations. The most important part of the proxy war is not the involvement of actors in the conflict, but the goals they can achieve through it. This leads to the conclusion that it is possible to achieve one's objectives not only in wartime but also in peacetime using the instruments mentioned in the smart power concept. A good example of this is the relationship between Iran and Hezbollah which is used as a proxy for pursuing Iran's interests. Such a relationship correlates with the notion of multi-levels of power because usually actors at a higher level use as their proxy entities at lower levels. Very often, these countries are chosen based on their geographical location such as the US-Egypt relationship or the US-Saudi Arabia relationship in the case of the Middle East.

In pursuing their position in the international arena and to become superpowers, states must first and foremost ensure that they have well-developed four main areas of their 
functioning, namely economy, politics, armed forces and scientific values. In today's world, these seem to be the most important areas of influence on other actors in international relations. They can be divided into two groups with reference to the concept of Joseph Nye: Soft power, i.e. political and intellectual power, and hard power, i.e. economic and military power. The bottom line is that if the state fails to attain its political goals and thus persuade others to act in a certain way with soft means of influence such as diplomacy or the gains derived from a given decision, then it may always backup soft means with hard power, such as economic sanctions or military force.

The pyramid of power

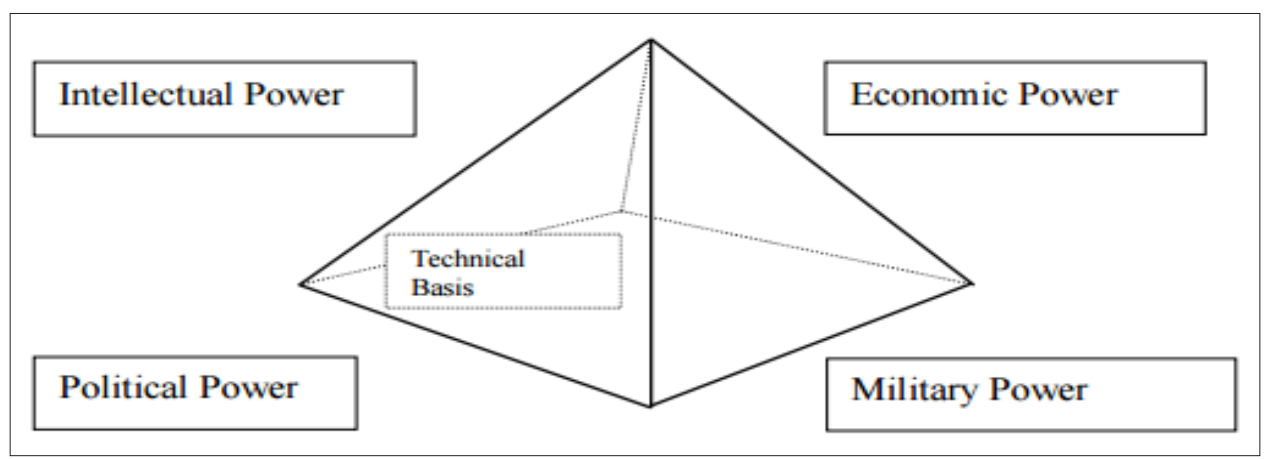

Source: Galice (2018)

What then is the concept of proxy war? In the author's opinion, it should be considered in a broader context than only the involvement of external actors in a war fought in a specific state. Proxy activities are all activities undertaken by an actor to obtain benefits. The current events in Syria have resulted in a situation where the presence of foreign actors is not aimed at resolving the conflict but has actually caused the problem today. When considering the pursuit of the interests of various actors in the Syrian war, four questions should be answered: "Where (on what level)?", "Why?", "Who?" and "How is it done?".

The conduct of proxy activities may be direct or indirect: direct through the use of Joseph Nye's concept of smart power and indirect through proxies.

\section{The proxy war in Syria}

\section{The national level}

Today's situation in Syria is the aftermath of the events associated with the Arab Spring in 2011. The simultaneous protests and uprisings of people living in countries of the Middle East and North Africa produced different results in individual countries. The ongoing debate on whether the Arab Spring is over or not is still valid, and scholars' 
opinions are divided. The uprising of Syrian citizens started in 2011. After several demonstrations, the regime of Bashar al-Assad decided to use force against its people. He sent armed forces to suppress demonstrations. Tanks were deployed against civilians and snipers fired on people. But the resistance was too strong for words to be killed with weapons. Citizens decided to share their experiences with the world. Videos, photos and stories about crimes committed by government forces began to appear on the Internet. The heterogeneous Syrian society began to divide into groups. A lack of cohesion, primarily religious, as this is the main factor determining and regulating the individual's belonging in the Arab-Muslim culture countries, has caused widespread opposition against the government. This has also been the cause of the internal division of the country, the Assad regime's lack of control over territory and a good launching pad for the development of the ideology of the 'Islamic State'.

At present, four main fronts of action can be distinguished, but this does not mean a clear division, as the situation in Syria is so complicated that some actors both cooperate with, and fight, each other. The most important force, which also determines the actions of others, is the regime of Bashar al-Assad, then there are the Kurds in the north of the country, numerous opposition groups, and the terrorist organization known as the 'Islamic State' (Arab acronym Daesh). However, it is worth noting that there is numerous opposition in the state of Bashar al-Assad and it is extremely difficult to name each of the groups with an indication of its allies and opponents.

Bashar al-Assad has been President of Syria since he took power from his father in 2000. The Assad family has ruled this country since a coup d'état in 1970. Since then, the power has been authoritarian, with the ruling establishment linked to Assad either directly or indirectly, through membership of the same religious group as the incumbent president. This behavior and the seizure of all positions by one religious group resulted in the creation of a monopoly on power by the Hafiz al-Assad family. However, years of authoritarian rule and the ongoing state of emergency, which gave additional powers to the state apparatus, as well as encouragement from successful revolutions in other countries (Tunisia, Egypt), caused Syrians also to decide to rise against the authorities. In the authorities' response to the rebellion that involved the use of armed forces, a certain precedent can be seen. Although it might seem like the best solution that would quickly bring order and allow for a return to the status quo, this has led to a collapse of power, as in the case of Libya, Yemen or Syria. The main objectives of President Bashar al-Assad are existential issues. His defeat and resignation may herald the same end as that of Muammar Gaddafi in Libya. But Assad does not fight for just his own existence; he is not alone in it. About $12 \%$ of the Syrian population are Alawites. It is one of the Shiite denominations to which the current President also belongs and through which the Syrian Government has the support of Iran, an important country in the region. At the beginning of the conflict, Bashar al-Assad still tried to use soft measures to 
influence his citizens by promising to lift the state of emergency and improve their lives. However, the key demand of the demonstrators was that he relinquishes power, and that was not fulfilled. Thus, the President's verbal appeal changed form by introducing hard means of influence, namely the use of armed force. The current situation benefits neither Syrian society nor the authorities, but the development of the situation has resulted in the involvement of external actors and it is currently unlikely that the crisis will end quickly.

Bashar al-Assad's actions have been strongly correlated with hard power actions. The Syrian president used security forces to fight to reclaim territory controlled by both the opposition and Daesh. In early 2013, pro-government forces launched an offensive to recapture territory in southern and western Syria. They received support from Hezbollah, who sent members of its military wing to fight the rebels (BBC, 2020). In August 2013, Assad's opponents accused him of using chemical weapons (Democracy Now, 2013, June 14). His situation began to deteriorate, and the range of his influence began to diminish. In September 2015, as Assad was increasingly losing control of the territory, Russian President Vladimir Putin ordered the launch of an air campaign in support of Assad. After regaining part of the territory with continued military support from allies, Assad was again accused of using chemical weapons. He was accused of using Sarin against rebel positions in Khan Sheikhoun in April 2017 and the toxic chemical chlorine in Douma in eastern Ghouta in April 2018. Hard power was Bashar al-Assad's only weapon in the struggle to keep himself and his followers in power.

Another group fighting in Syria is the broadly understood opposition. The lack of control of state institutions over the country's borders has resulted in a large influx of foreigners and the creation of many opposition groups. This has also allowed terrorist organizations such as Daesh and the Al-Nusra Front to take root and facilitated the influx of foreign fighters into these groups. Most of the demands include the removal of Bashar al-Assad from power. Every organization has a different plan for the future of the Syrian state, but most of them pursue their demands through the hard means of influence involving the use of weapons. In this state-level conflict, you can barely notice any soft means of influence to be used by hostile groups, as most of them have weapons at their disposal and are determined to resolve any issues by force.

The next important group are the Kurds. It is the largest ethnic group that does not have a state they can call their own. For many years, their main strategic goal has been to create their own country. Currently, they are residing in four countries: Turkey, Iraq, Iran and Syria. In Syria, they account for $10 \%$ of the population (BBC, 2019). Their involvement in the Syrian conflict is of twofold importance. Firstly, they are fighting about existential issues. The imminent threat from the Islamic State forced them to take up arms against the organization's fighters. The Kurds are also proxies for Western states that give weapons and provide training to the Kurds treating them as land forces for the 
Operation Inherent Resolve against the Islamic State. The event that shook the Kurdish alliance with the coalition of Western countries was the 2019 withdrawal of US troops and the Turkish offensive on Kurdish lands. The Kurds felt betrayed by their allies. Fox wrote about proxies changing patronage and the fact that the proxy-guardian relationship is not sustainable. In this case, the Kurds became isolated and "sold" to Turkey, so they asked Bashar al-Assad for help. He assured them of his help in regaining their territory. The second factor that appeared when the Kurds joined the fight stems from their willingness to create their state. Charles Tilly formulated the thesis that "states make war and wars make states" (Zdanowski, 2014, p. 8).

The last important actor, extremely significant in the area of terrorism, is the Islamic State as the main actor in the conflict in Syria. This terrorist organization in its current name and form was established in 2014. The civil war waged by citizens against the rule of Bashar al-Assad has given members of this group the opportunity to anchor their bases and networks in the territory of this state. In its heyday, Daesh held about a third of Syria's territory. This was the case until December 2017, when the organization lost $95 \%$ of its territory, including its capital in the northern Syrian city of Raqqa (Wilson Center, 2019). What is important about this organization and its impact on the situation in the region and in Syria itself is the fact that the authorities of the Islamic State strive, through their actions, to create a caliphate, i.e. to establish a state under their leadership based on Islamic law and principles. This is another actor that hopes that their activities will benefit them in the form of their caliphate, which became the case on 29 June 2014. Many theories explain the creation of Daesh. One of them indicates that it was established as part of the aid from Saudi Arabia and was intended to be a creation aimed against Iran to weaken its position and against the regime of Bashar al-Assad to remove it from power. A similar theory applies to the support of the Islamic State by the government in Tehran that directs the activities of this organization to undermine the regional power represented by the government in Riyadh. There are also theories that Daesh is a US-backed organization created to destabilize the Middle East and provide the US with a justification to maintain a permanent presence in the region or an organization established as an anti-American vehicle by Russia. There is much speculation on this topic, but it is well known that each side supports groups targeted against its political opponents, even if they are terrorist organizations if aiding them, even only financially, can weaken the opponent.

\section{The regional level}

At the regional level, the rivalry is primarily between two players, Saudi Arabia and Iran, both of which consider themselves religious powers (of a particular sect of Islam). This political game of influence is being driven by the attempt to achieve religious dominance, which plays a major role in Middle Eastern countries. Saudi Arabia and Iran are not 
interested in engaging in an open and costly conflict; nevertheless, they seek to expand their influence to the greatest extent possible (Dzisiów-Szuszczykiewicz, 2014).

Saudi Arabia is one of the largest countries in the Middle East. It is a key ally of the United States which is a beneficial status indeed. Saudi Arabia's population is approximately $28,160,273.85-90 \%$ of the Saudis are Sunnis, the remaining $10-15 \%$-Shiites. The main objectives that the Riyadh government attempts to pursue by engaging in the Syrian conflict include increasing Saudi Arabia's regional standing, undermining their primary adversary, the Islamic Republic of Iran, and replacing Syria's leadership with a pro-Saudi regime (Berti \& Guzansky, 2012). Saudi Arabia acts using both soft and hard measures of influence. The former include TV and radio propaganda efforts taken as part of the dissemination of cultural values. Before the conflict broke out into its present form, these were useful measures for spreading one's ideology among the population of another country, and for gaining allies. The projection of Sauds' soft power includes the opening of schools as part of spreading their values and convincing others that their actions are beneficial. Saudi Arabia also deploys a "Sunni security umbrella" based on religious values. By portraying themselves as protectors of fellow believers, Saudi Arabia is claiming the right to intervene in other parts of the region (as a regional power) whenever their protection is needed. As far as hard power is concerned, Saudi Arabia primary effort is the participation in the US-led coalition against the so-called Islamic State. Another item in the hard power arsenal used by Saudi Arabia is economic measures. Given the size of the opposition in Syria, the Riyadh government can choose the groups whose goals are most aligned with the Saudi agenda or those most controllable. In addition to financing the opposition, Saudi Arabia has created a special fund to pay deserters from Assad's army. Saudi Arabia also seeks to exploit opportunities resulting from tribal allegiances. The popular uprisings against the government which erupted during the Arab Spring provided an opportunity for Riyadh to replace the Damascus regime with a pro-Saudi government by taking advantage of the tribes that rose against Assad. Saudi Arabia has provided financial and military support to the Syrian opposition. It also invited tribal sheikhs for talks to maintain their favour by offering shelter and financial assistance. This led to the escape of 20 tribal leaders who took refuge in Saudi Arabia.

The actions of the Islamic Republic of Iran mirror those taken by Saudi Arabia. The authorities in Tehran aim to strengthen their position, weaken Saudi Arabia's standing and keep the Damascus regime in power. Bashar al-Assad is an important ally of Iran. Syria is the main pathway for arms and money supplies to another Iran's proxy, Lebanon's Hezbollah. Describing strategic depth in political terms, the government in Tehran expands its territory through various groups in other countries, ensuring the achievement of Iran's policy objectives through proxy actions and groups like Hezbollah in Lebanon or the Hutis in Yemen (Akbarzadeh, 2017). By exercising its soft power, Iran, 
similarly to Saudi Arabia, promotes its ideology through radio or television broadcasts and opens schools engaged in the advocacy of Iran's ideological agenda. Like the Riyadh government, the government in Tehran is convinced of its superiority in terms of religious leadership (Shiism). Iranian missionaries are working to convert the Baggara tribe of DeizEzzor to the Shiite strain of Islam to counterbalance the power of the Sunni Aqaydate tribe. Using soft power, Iran supports and promotes Syrian tourism by subsidizing air-and-hotel holidays to Syria. As a result, one million Iranian tourists visited the Shiite shrine of Sayyid Zaynab in Damascus (Sadjadpour, 2013). As far as hard power is concerned, Iran uses military and economic measures. The government in Tehran supports President Bashar al-Assad militarily by supplying arms and ammunition and deploying Iranian military forces. Since 2017, Iran has been supporting specific brigades in the Syrian army and setting up private security companies in Syria. Such companies have been legally authorized to operate in Syria, and for Iran, they provide cover for registered Syrian companies. This allows Iran to maintain a military presence in strategic locations in Syria (Saban, 2020). The Islamic Republic of Iran is also engaged in the economic field, financing Iran-friendly opposition and the President of Syria. Iran is also pouring large sums into the training of the Tay and Sheitat tribal militias fighting alongside the Syrian government's forces. In 2013, the Syrian state media announced another measure of financial support, a "credit agreement" with Iran worth USD 1 billion. Five months later, Syrian officials informed that Iran had granted Syria an additional loan of USD 3.6 billion (Sadjadpour, 2013).

The level of regional competition is a kind of "mini global level". Iran can be compared to Russia, especially given the close ties between the countries. Both Iran and Russia have been targeted by sanctions imposed by the international community, the former because of its nuclear program, the latter-in response to the situation in Ukraine. However, although the main purpose of the restrictions was to weaken both states and marginalize them as pariahs of international relations, it has become clear that without the participation of Iran and Russia, the Syrian conflict would not be resolved.

Here, the religious aspect of soft power is crucial. Religion is extremely important for virtually everyone living in Arab-Muslim countries. Iran and Saudi Arabia, each of whom considers itself a religious beacon (for Shiites or Sunnis), wage religious wars away from their territory to define their respective borders.

\section{The global level}

On the global level, the proxy war in Syria involves two important actors: the United States and Russian Federation. Both countries compete in different fields and different regions of the world. As the Syrian conflict erupted, the competition between Russia and the US extended into the Middle East. Both countries' involvement in the Syrian conflict is remarkably similar. What differentiates the US approach to the conflict from that of Russia is that the United States decided to limit their involvement as a key player in 
Bashar al-Assad's state. Both countries support opposition groups and make extensive use of their military resources, and also have deployed troops inside Syria. Although the powers try to avoid a confrontation, seven US soldiers were injured in a collision with a Russian vehicle in late August 2020. The US and Russian governments blamed each other for the incident.

For the United States, the Middle East is a field for playing their global game. The US administration seeks to install sympathetic governments to advance their interests in the Middle East region. The United States pursues their own goals at every level: global, regional and national. On the national level, the US strategy is driven by the desire for a change of regime in Syria. Bashar al-Assad is not an ally of the West, and the Arab Spring and subsequent developments have led the United States to see the possibility of a replacement. However, following their previous experiences, the US had no intention of re-deploying their military in the Middle East en-masse for an extended period. The Obama administration, wishing to avoid repeating J. W. Bush's mistakes in Iraq and Afghanistan, has avoided direct intervention and chose to indirectly oppose Bashar al-Assad (Hashemi \&Sahrapeyma, 2018). For this reason, the Obama administration acted with restraint. Above all, the US took diplomatic action and financially supported the opposition and the Kurds. The US supports the Kurdish People's Protection Unit fighting Daesh (Byman, 2018). The United States hoped that, with their backing, there would be a change of government in Syria and that the new regime would be sympathetic to US policies. However, the United States is also well aware that forcibly overthrowing Assad will not solve their problem, especially since the US does not have a concrete plan for replacing the Syrian President and wants to avoid a situation resembling the Libyan debacle. At the regional level, the US policy is to support its ally Saudi Arabia while keeping a watchful eye on Iran. If the United States were to cooperate with Tehran, it would jeopardize its relations with Riyadh. At the global level, US actions are a consequence of the American competition with the Russian Federation. Deployment of Russian troops in Syria may lead to a gradual loss of American influence in the region. A change of regime in Syria could also result in the construction of a gas pipeline from Qatar, a project that would dismantle Russia's gas monopoly in Europe. Such a development would have a significant impact on Russia's economy. It would enable the United States to continue the consolidation of its global position.

As part of the US-projected hard power, one should above else notice the creation of a military coalition as part of the Operation Inherent Resolve, which comprised air force assets used against the so-called Islamic State. In this case, the Syrian Democratic Forces have been a proxy for the US since October 2014 (Fox, 2019). There is also an economic factor. The US financially supports the Syrian opposition and, above all, the Kurdish forces. Qatar, in collaboration with the US, sent the opposition USD 3 billion and 79 shipments of military ordnance. 
Actions taken by the US include soft power measures such as the attempted UN resolution to impose sanctions on the Assad government, which was vetoed by Russia and China. Despite cultural and religious differences, American values related to science, education and democracy may have a certain appeal to younger generations of Arabs and as such may constitute an added value for the US.

The other major global player in Syria is the Russian Federation. For Moscow, involvement in the Syrian conflict is extremely important. The developments in Syria coincided with an international outcry against Russia's actions in Ukraine. Moreover, the government of Bashar al-Assad is one of the few allies of the Kremlin, so it is strategically important for Russia to keep him in power or ensure that Assad's successor also supports Russian interests. Currently, Russia has two military bases in the Syrian territory: the naval base in Tartus and the airbase in Chmejmin. In addition, the Russians deployed anti-aircraft systems and warships with cruise missiles. In 2017, the Russian Ministry of Defence reported that around 600 new weapon systems were tested in military operations in Syria (Petkova, 2020). The Russians supplied tons of ammunition to the Syrian security forces. According to some estimates, $10 \%$ of Russia's global arms sales went to Syria with the value of contracts in 2012 estimated at USD 1.5 billion. Apart from munitions, the sales included military training aircraft, air defense systems and anti-tank weapons (Galpin, 2012). Russia supports Assad through Syrian proxies, private military companies, and Chechen client forces, in coordination with its armed forces (Fox, 2019).

Syrian and Russian governments have also signed a treaty, ratified by the lower house of the Russian parliament, which stipulates that Russian forces may remain in Syria for an indefinite period. Protecting its military presence in the Middle East is only one of the factors of Russia's involvement in the Syrian conflict. This provides an opportunity for the Kremlin to become actively involved in the Middle East power play. Another of Russia's goals is to become a counterbalance in the MENA region. This means that the Kremlin seeks to obtain a status of a partner (and patron) of states located in that region, alongside the United States. Involvement in Syria also provides Russia with economic benefits. By supporting Assad, Russia gains the opportunity to sell its weapons. The Syrian affair is also beneficial to the Russian military, for whom the Syrian territory is a testing ground for military equipment. The long-term goal of Russia's involvement in the conflict is to improve its relations with the European Union. The West imposed sanctions on Russia for its involvement in the conflict in Ukraine. In this regard, Russia has become such an important actor in the discussed conflict that it is impossible to end it without commencing negotiations with the Kremlin. This leads to the situation that European states, despite their restraint, must cooperate with the Russians if they want to end this war. Russia engaged in the fight against the so-called Islamic State out of concern for the spread of the radical Islamic ideology to the former Soviet republics, 
seeking to avoid a situation similar to that currently unfolding in Syria. Russia's involvement in an international conflict shifts Russians' attention away from a bad domestic situation and provides an opportunity to boost the image of the country's armed forces.

As a soft power move, Russia offered to host peace talks in Moscow, a proposal the Syrian government agreed to. However, the opposition Syrian National Council rejected the offer, saying President Assad must step down before any negotiations could take place (Galpin, 2012). Russia also became involved in the Kurdish affair. The Kremlin has taken another soft power measure inviting rival Kurdish groups to Moscow in an attempt to bring unity between them. However, the Kurds, and especially the dominant PYD faction, are distrustful of Russia because of its alliance with Turkey (Aftandillian, 2021). Finally, Russia's soft power actions included supporting Bashar al-Assad in the United Nations. Together with China, Russia vetoed three UN Security Council resolutions that sought to authorize measures against the Syrian government (Charap, Tryger, \& Geist, 2019).

\section{Summary}

Carl von Clausewitz said that war is nothing but a continuation of politics (Lindell, 2009). Today, this can be translated into a concept proxy war. It is nothing more than the involvement of third parties in a war in a foreign territory between other actors to pursue their interests. As demonstrated in the text, this can be done in two ways, namely through hard and soft means of influence. Clausewitz's theory is reflected in the 21 st century only now it is called differently. Secondly, while analyzing the paper's topic that is the issue of terrorism being a catalyst of proxy war, it can be deduced that it is a license permitting the conduct of proxy activities provoked by terrorist actions. It is a well-known fact that armed intervention cannot be carried out in another country without a legitimate reason, and the fight against a terrorist organization such as the Islamic State makes the intervention permissible. In the 21st century, there is an increasing tendency among states to conduct their policies and pursue their aspirations to become superpowers by means of soft power. However, they often use hard power such as military or economic force in the form of sanctions, for example, to back up their operations and affairs handled through soft means of influence. What should be important for foreign powers and attempts to unravel the situation in Syria, which has a negative impact on security not only in the region but also in the world, is to resolve the issue of the terrorist organization - the Islamic State. Still, the focus is on the government of Bashar al-Assad, with different actors seeking either to remove it from, or leave it in, power. Meanwhile, "ironically, the black beast in 2014 somehow turned out to be agreeable to everyone and everyone tried to tame it instead of killing it" (Grzenia \& Moskwa, 2016). Daesh, which was supposed to be an "ally" for each party aiming to further their interests, became an independent entity. Despite the organization's crimes, it is hard to deny that it is thanks to the Islamic State that other actors are going ahead with their plans. 


\section{References}

1. Aftandillian, G. (2021, January 13). Kurdish dilemmas in Syria. Arab Center Washington DC. Retrieved from http://arabcenterdc.org/policy_analyses/kurdish-dilemmas-insyria/.

2. Akbarzadeh, S. (2017). Iran's uncertain standing in the Middle East. The Washington Quarterly, 40(3), 109-127.

3. Bania R., Woźniak, M., \& Zdulski, K. (2011). Rewolucje w świecie arabskim. Aspekty polityczne, społeczne i humanitarne [Revolutions in the Arab World. Political, social and humanitarian aspects]. Wydział Informacji 0 Krajach Pochodzenia, Urząd Do Spraw Cudzoziemców [Department of Country of Origin Information, Office for Foreigners].

4. BBC. (2019, October 15). Who are the Kurds? Retrieved from https://www.bbc.com/ news/world-middle-east-29702440.

5. BBC. (2020, August 31). Syrian President Bashar al-Assad: facing down rebellion. Retrieved from https://www.bbc.com/news/10338256.

6. Berti B., \& Guzansky, Y. (2012), The Syrian crisis and the Saudi-Iranian rivalry. Foreign Policy Research Institute.

7. Byman D. L. (2018, May 21). Why engage in proxy war? A state's perspectives. Brookings. Retrieved from https://www.brookings.edu/blog/order-from-chaos/2018/05/21/ why-engage-in-proxy-war-a-states-perspective/.

8. ÇAĞLAYAN, M. (2016, FEBRUARY 23). Syria conflict becomes 'multisided proxy war', says UN. Anadolu Agency. Retrieved from http://aa.com.tr/en/politics/syria-conflict-beco mes-multisided-proxy-war-says-un/525647.

9. Charap S., Tryger E., \& Geist E. (2019). Understanding Russia's intervention in Syria. RAND Corporation.

10. Democracy Now. (2013, June 14). Patrick Cockburn on U.S. Plans to Arm Syrian Rebels: Where is the Skepticism About Chemical Weapons?. Retrieved from https://www.de mocracynow.org/2013/6/14/patrick_cockburn_on_us_plans_to.

11. Dzisiów-Szuszczykiewicz, A. (2014). Bliskowschodnia „zimna wojna” czyli saudyjsko -irańska rywalizacja w regionie w obliczu „arabskiej wiosny”. Bezpieczeństwo Narodowe, II, 181-206.

12. Fox, A. C. (2019). Conflict and the need for a Theory of Proxy Warfare. Journal of Strategic Security, 12(1), 44-71.

13. Galice, G. (2018, November 28). States of war and Proxy wars- nowadays. Institut International de recherches pour la paix à Genève. Retrieved from http://www.gipri.ch/?s= States+of+War+and+Proxy+Wars+nowadays.

14. Galpin, R. (2012, January 30). Russian arms shipments bolster Syria's embattled Assed. $B B C$. Retrieved from https://www.bbc.com/news/world-middle-east-16797818.

15. Grzenia, R., \& Moskwa, M. (2016). Sura. Prześwit.

16. Hashemi S. A., \& Sahrapeyma, M. (2018). Proxy war and US's smart-power strategy (the case of Syria, 2011-2016). The Quarterly Journal of Political Studies of Islamic World, 6(24), 83-101. 
17. Lindell J. (2009). Clausewitz: war, peace and politics. Retrieved from https://www.e-ir. info/2009/11/26/clausewitz-war-peace-and-politics/.

18. Łoś-Nowak, T. (2002). Stosunki międzynarodowe. Zakamycze, p. 221

19. Miłoszewska, D. (2010). Trójpłaszczyznowa szachownica. Instytut Geopolityki.

20. Mumford A. (2013). Proxy warfare and the future of conflict. The RUSI Journal, 158(2), 40-46.

21. Peralta, E. (2015, October 17). We ask experts: Has the Situation in Syria become a proxy war? The Two-Way. Retrieved from http://www.npr.org/sections/thetwo-way/ 2015/10/16/449181764/we-ask-experts-has-the-situation-in-syria-become-a-prox y-war.

22. Petkova, M. (2020, October 1st). What has Russia gained from five years of fighting in Syria?. AlJazeera. Retrieved from https://www.aljazeera.com/features/2020/10/1/ what-has-russia-gained-from-five-years-of-fighting-in-syria.

23. Porter. G. (2015, May 6). The media misses the point on 'proxy war'. Middle East Eye. Retrieved from http://www.middleeasteye.net/columns/media-misses-point-proxywar-1956459570.

24. Saban, N. (2020). Factbox: Iranian influence and presence in Syria. Retrieved from https://www.atlanticcouncil.org/blogs/menasource/factbox-iranian-influence-andpresence-in-syria/.

25. Sadjadpour, K. (2013, August 27). Iran's unwavering support to Assad's Syria. Carnegie Endowment for International Peace. Retrieved from https://carnegieendow ment.org/2013/08/27/iran-s-unwavering-support-to-assad-s-syria-pub-52779.

26. Wilson Center. (2019, October 28). Timeline: The rise, spread, and fall of the Islamic State. Retrieved from https://www.wilsoncenter.org/article/timeline-the-rise-spreadand-fall-the-islamic-state.

27. Zdanowski J, (2014). Państwo na muzułmańskim Bliskim Wschodzie. Procesygenezyiczynnikitrwania [The State in the Muslim Middle East. Processes of genesis and factors of duration], Kraków: Krakowskie Towarzystwo Edukacyjne sp. z o.o. - Oficyna Wydawnicza AFM. 